\title{
A RELATIONSHIP BETWEEN THE COMPOSITION OF THE URINE AND THAT OF URINARY TRACT CALCULI IN SPINAL PATIENTS
}

\author{
By R. G. Burr, M.Sc., C.Chem., M.R.I.C. \\ National Spinal Injuries Centre, Stoke Mandeville Hospital, Aylesbury, \\ Buckinghamshire, England
}

\begin{abstract}
Chemical analysis was carried out on 42 urinary phosphatic calculi obtained from I4 spinal cord patients (two to seven stones per patient) and on small samples taken from different sites in a further 17 large phosphatic calculi.

In 'early' stones (removed up to 30 months after onset of the cord lesion) the ratio of calcium to magnesium was significantly higher than in 'late' stones. Samples taken from sites nearer to the centres of calculi contained more calcium and less magnesium than did those from more peripheral sites.

This change in the composition of urinary calculi with time corresponds with the known alterations in urinary calcium and magnesium following spinal cord injury.
\end{abstract}

Key words: Paraplegia; Urinary calculi.

THE major components of most urinary stones produced by paraplegic patients are calcium phosphate and magnesium ammonium phosphate (Comarr, Kawaichi \& Bors, 1962; Damanski, 1963) indicating the important role played by bacterial urease in their formation (Griffith, Musher \& Itin, 1976).

In an earlier study (Burr, I978), a relationship was observed between the ratio of the two main crystalline constituents and the duration of the spinal cord lesion: the calcium content of the calculi fell and the magnesium content increased with increasing time after the onset of paralysis. The ratio was independent of the level of the cord lesion, the sex of the patient, or the anatomical site of the stone. By contrast, Claus-Walker et al. (1973) reported a significant difference in the composition of bladder stones depending on the level of the lesion: calculi from paraplegics contained more calcium and less magnesium than those from quadriplegic patients. The calcium content of the calculi was, however, unrelated to the duration of paralysis.

In this paper further evidence is reported which demonstrates a relation between stone composition and time, and the relation is explained in terms of the change in urinary composition with time.

\section{Material and Methods}

The calculi analysed had been removed from the urinary tracts of patients at this Centre over an II-year period beginning October 1965. The results for the main group are reported elsewhere (Burr, 1978). Review of this material showed that I4 patients had produced more than one stone (in all, I 7 kidney and 25 bladder stones). The calcium to magnesium ratio $(\mathrm{Ca} / \mathrm{Mg})$ for each stone was compared with that of the next from the same patient in the following way: the stones were arranged in chronological order and then collected into adjacent 
pairs; all the firsts of the pairs were then compared with all the seconds. Bladder stones were treated separately from kidney stones except where a patient had produced only one from each site. This yielded 25 pairs: five of kidney stones, I4 of bladder stones, and six mixed.

From a further I 7 large calculi small samples were taken for analysis from different parts of the stone to permit comparison between central and peripheral regions. Calcium, magnesium and phosphate were determined by the methods used previously (Burr, I978).

Twenty-four-hour urine collections were obtained from 3 I male patients with stones more than 2 years after the onset of paralysis. Calcium was determined by automated spectrophotometry (Clark et al., I975) and magnesium by automated fluorimetry (Klein \& Oaklander, 1967). These results were compared with those of 50 male patients during the seventh week of paralysis, and also with serial urine analyses carried out of 83 male patients for the first 5 months following the onset of paralysis (Burr \& Walsh, 1974).

In comparing the different groups, $\log (\mathrm{Ca} / \mathrm{Mg})$ was used in preference to $(\mathrm{Ca} / \mathrm{Mg})$ because of the less skewed distribution of the logarithmic data.

\section{Results}

Figure I shows the alteration in $\mathrm{Ca} / \mathrm{Mg}$ ratio with time when more than one stone was obtained from the same patient. The results fell into two groups. For 'early' stones (first of pair obtained less than 30 months after onset of cord lesion) the ratio differed significantly $(\mathrm{P}<0.025$; paired $T$ test), but for 'late' stones (first of pair 30 or more months after onset of lesion) the difference between the first and second ratios of the pair was not significant $(\mathrm{P}>0.05)$. There were ten pairs of results (four patients) in the 'early' group and I5 (ten patients) in the 'late' group.

Figure 2 shows the results of analysing samples from different stone sites. The difference in ratio was significant $(\mathrm{P}<0.05$; paired $T$ test $)$ whether the centre

SUCCESSIVE CALCULI IN THE SAME PATIENT

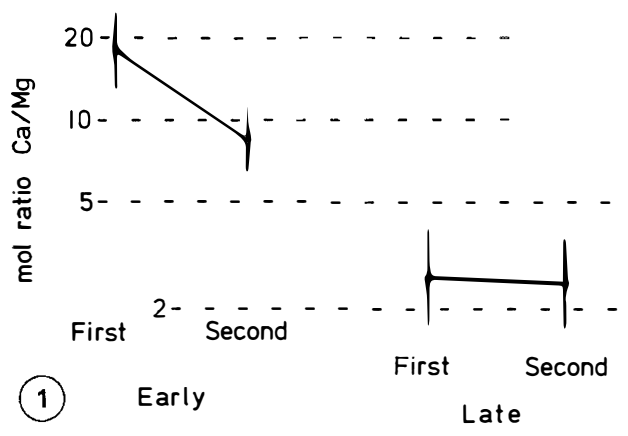

FIG. I

Ratio of calcium to magnesium in samples representative of whole calculus. 'Early' calculi were those produced within 8 years of the onset of paralysis. 'Late' calculi were produced after more than 8 years paralysis. For statistical treatment the calculi were arranged in consecutive pairs. Vertical lines represent \pm I SEM. 


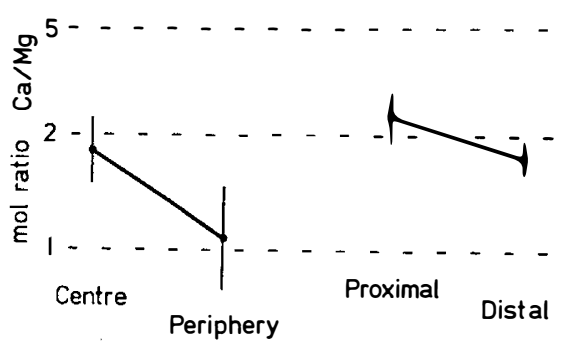

(2)

FIG. 2

Ratio of calcium to magnesium in samples taken from different regions of calculi. Vertical lines represent \pm I SEM.

of each calculus was compared with the periphery, or whether more central regions were compared with areas nearer the cortex.

The results of the urine analyses are shown in Figure 3. Data for the specimens obtained during the seventh week of paralysis are compared with those obtained 2 or more years after onset. Magnesium excretion did not differ between the two groups, but there were significant differences both in calcium excretion and in $\mathrm{Ca} / \mathrm{Mg}$ ratio $(\mathrm{P}<0.00 \mathrm{I}$; unpaired $T$ test $)$.

URINARY EXCRETION IN SPINAL

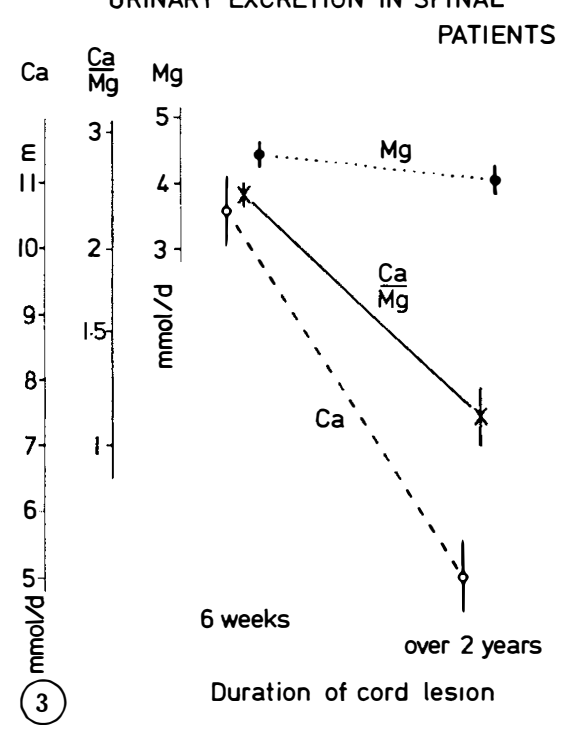

FIG. 3

Urinary calcium, magnesium and calcium to magnesium ratio in patients with spinal cord lesions. Specimens obtained from 50 male patients during the seventh week of paralysis are compared with those obtained from $3 \mathrm{I}$ male patients with urinary calculi more than 2 years after the onset of paralysis. Vertical lines represent \pm I SEM. 


\section{Discussion}

The data of Figures I and 2 confirm the inverse relation between $\mathrm{Ca} / \mathrm{Mg}$ ratio and time previously reported for a collection of 148 calculi (Burr, I977). In the four patients who formed more than one 'early' stone, succeeding stones had significantly lower ratios than those that preceded them. In the ro patients who produced more than one 'late' calculus, successive calculi did not differ. Moreover, the ratios for the 'late' calculi were significantly lower than those of the 'early' calculi.

$\mathrm{The} \mathrm{Ca} / \mathrm{Mg}$ ratios also fell significantly on proceeding from the centre towards the periphery of the 17 calculi examined. The differences in this instance were only just significant, but these were all large calculi, and therefore had low overall $\mathrm{Ca} / \mathrm{Mg}$ ratios (Burr, I977).

Paraplegic patients are known to have elevated urinary calcium excretion during the first I or 2 years of their condition. Apart from a brief early episode of hypermagnesuria the urinary magnesium is close to normal in spinal patients (Burr \& Walsh, 1974). It is to be expected, therefore, that the urinary $\mathrm{Ca} / \mathrm{Mg}$ ratio will alter with time, being elevated during the first year or so, and later declining to a much lower level. The data presented in Figure 3 bear this out.

The inverse relation between $\mathrm{Ca} / \mathrm{Mg}$ ratio and time observed both in urine samples and in calculi from spinal patients indicates the existence of a simple relationship between urine composition and stone composition, and suggests that the concentrations of stone-forming salts in urine is directly related to their concentrations in the material being laid down in the stone in contact with that urine. This observation is consistent with the view that a calculus grows by the nonselective accretion of precipitated material from oversaturated urine, oversaturation in this instance being caused by elevation of $\mathrm{pH}$ and ammonium concentration resulting from hydrolysis of urinary urea by bacterial urease.

A corollary of this concept is that rational stone therapy depends on the maintenance of an undersaturated urine. In practical terms for paraplegic patients this means the maintenance of a sufficiently acid, or a sufficiently dilute, urine. Perhaps the most promising avenue at present is urease inhibition as advocated by Griffith, Gibson et al. (1976).

Inspection of the data published by Claus-Walker et al. (I973) (Table I) shows agreement with the urine-stone relationship postulated here. The difference in $\mathrm{Ca}$ analysis was just significant for the stones $(\mathrm{P}<0.05)$, but not significant for the urines, however.

It is more difficult to explain why the duration of paralysis was unrelated to stone composition in their results, but the two sets of material are not strictly comparable. The corresponding numbers of stones are shown in Table II. The Aylesbury material is thus heavily weighted by much later stones.

\section{TABLE I}

\begin{tabular}{lcc}
\hline & $\begin{array}{c}\text { Stones } \\
\text { Ca }(\% \text { of total weight })\end{array}$ & $\begin{array}{c}\text { Urines } \\
\mathrm{Ca}(\mathrm{mEq} / \mathrm{l})\end{array}$ \\
\hline & & 2.99 \\
tetraplegics & 17.5 & 4.60 \\
\hline
\end{tabular}


TABLE II

\begin{tabular}{lccc}
\hline & $\begin{array}{c}\text { Under } \\
\text { 2 years }\end{array}$ & $\begin{array}{c}\text { Over } \\
\text { 2 years }\end{array}$ & $\begin{array}{c}\text { Over } \\
\text { 10 years }\end{array}$ \\
\hline Claus-Walker et al. (1973) & 2I & 6 & 0 \\
Burr (I977) & 44 & 96 & 67 \\
Present & IO & 32 & 2 I \\
\hline
\end{tabular}

\section{SUMMARY}

Chemical analysis was performed on 42 urinary phosphatic calculi obtained from I4 patients (two to seven stones per patient) and on small samples taken from different sites of a further 17 large phosphatic calculi.

'Early' calculi (removed up to 30 months following the onset of the cord lesion) had significantly higher ratios of calcium to magnesium than did 'late' stones. Similarly, samples taken from sites near to the centres of calculi contained more calcium and less magnesium than samples from more peripheral sites. These observations confirm the results of a previous study of 145 calculi in which the calcium to magnesium ratio of phosphatic calculi was inversely related to the duration of paralysis.

Urinary calcium excretion is known to be elevated during the first year following the onset of paralysis, falling thereafter to normal levels. Magnesium excretion does not alter significantly after the second month. The change in the composition of calculi with time therefore parallels the alteration in the urinary calcium to magnesium ratio.

\section{RÉSUMÉ}

L'analyse chimique de 42 calculs urinaires phosphatiques (2-7 calculs par patient à différents moments) fut faite ainsi que celle de petits échantillons prélevés dans différentes régions de 17 autres gros calculs phosphatiques.

Les 'vieux' calculs (enlevés au bout de 30 mois après le début de la lésion médullaire) avaient un rapport calcium à magnésium beaucoup plus élevé que celui des calculs de formation récente. De même, les échantillons prélevés près du centre des calculs contenaient plus de calcium et moins de magnésium que les échantillons prélevés sur la surface des calculs. Ces observations confirment les résultats d'une étude précédente de I 45 calculs dans lesquels le rapport calcium à magnésium des calculs phosphatiques était inversement proportionel à la durée de la paralysie.

On sait que l'excrétion du calcium est elevée durant la première année après le début de la paralysie et diminue ensuite jusqu'aux taux normals. L'excrétion du magnésium ne change pas d'une manière significative après le second mois. Le changement dans la composition des calculs avec le temps est donc analogue au changement du rapport des taux de calcium au magnésium urinaire.

\section{ZUSAMMENFASSUNG}

Eine chemische Analyse wurde an 42 Phosphatsteinen durchgeführt, die von I4 Patienten zu verschiedenen Zeitpunkten gewonnen wurden (2-7 Steine pro Patient); ebenso an an verschiedenen Stellen der Steine entnommenen Teilstücken von weiteren 17 grossen Phosphatsteinen.

'Frühe' Steine (bis zu $30 \mathrm{Mt}$. nach Einsetzen der Querschnittslähmung entnommen) zeigten einen signifikant höheren Kalzium-gehalt gegenüber Magnesium als 'späte' Steine. Ebenso enthielten zentral entnommene Teilstücke eines Steines mehr Kalzium und weniger 
Magnesium als peripher gelegene. Diese Beobachtungen bestätigen die Resultate einer früheren Studie, wonach sich die Kalzium/Magnesium-relation in Phosphatsteinen umgekehrt zur Dauer der Querschnittslähmung verhält.

Es ist bekannt, dass die Kalziumausscheidung im ersten Jahr nach Einsetzen einer Querzschnittslähmung erhöht ist und nachher wieder auf normale Werte fällt. Die Magnesiumausscheidung ist nicht mehr signifikant verändert nach dem 2. Monat. Der Wechsel in der Zusammensetzung von Steinen im Verlaufe der Zeit geht also parallel mit dem Wechsel des Kalzium/Magnesium-verhältnisses im Urin.

Acknowledgements. I thank Dr A. Barr for the statistical calculations, R. Hill and Pamela Smith for technical assistance, and Dr J. J. Walsh for his interest and support.

\section{REFERENCES}

BURR, R. G. (I978). The composition of urinary calculi from patients with spinal cord lesions. Arch. Phys. Med. Rehabil., in press.

BURR, R. G. \& Walsh, J. J. (I974). Urinary calcium and kidney stones in paraplegia. Report of an attempted prospective study. Paraplegia, 12, 38-43.

Clark, W. L., Baginski, E. S., Marie, S. S. \& ZAK, B. (I975). Spectrophotometric study of a direct determination of serum calcium. Microchem. F. 20, 22-32.

Claus-Walker, J., Campos, R. J., Carter, R. E. \& Chapman, M. (I973). Electrolytes in urinary calculi and urine of patients with spinal cord injuries. Arch. Phys. Med. Rehabil. 54, I09-II4.

Comarr, A. E., KaWAICHI, G. K. \& Bors, E. (1962). Renal calculosis of patients with traumatic cord lesions. F. Urol. 87, 647-656.

Damanski, M. (1963). Stone disease in paraplegia. Paraplegia, I, I49-1 56.

Griffith, D. P., Gibson, J. R., Clinton, C. W. \& Musher, D. M.(1976). Acetohydroxamic acid: initial investigations in man. In Urolithiasis Research, ed. H. Fleisch, W. G. Robertson, L. H. Smith \& W. Vahlensieck. Plenum Press, New York and London, pp. 545-548.

Griffith, D. P., Musher, D. M. \& Itin, C. (1976). Urease. The primary cause of infection-induced urinary stones. Invest. Urol. 13, 346-350.

KLEIN, B. \& OAKLANDER, M. (I967). The automated flurimetric determination of serum magnesium. Clin. Chem. 13, 26-35. 